\title{
TSUNAMI RISK IN NEW ZEALAND
}

G. A Eiby

Seismological Observatory Wellington

The manner in which an earthquake produces a tsunami, or seismic seawave, is not well understood. In Japan and in Chile they accompany most large shallow submarine earthquakes close to the coast, while in New Zealand and much of the South West Pacific tsunamis of local origin have been of comparatively rare occurrence, and are usually small. Nevertheless, both tsunamis and seiches (resonant oscillations of enclosed bodies of water) constitute an appreciable component of our earthquake risk.

\section{Nature and origin of tsunamis}

A tsunami travels as an ordinary gravity wave on the surface of the ocean. Its wavelength is usually of the order of several hundred kilometres, its period some tens of minutes, and its amplitude small, perhaps less than a metre. Its velocity depends upon the depth, according to the relation

$$
V=(g h)^{\frac{1}{2}}
$$

and can reach 300 metres/sec (approximately 600 miles/hr) over the deep ocean basins. When the front of such a wave reaches a shallowing coast, the first water to arrive is delayed, and a piling-up occurs, so that the breaking wave may be of great height and destructive power. Confinement in bays or estuaries may further increase the effects. A tsunami in Kamchatka in 1737 is reported to have reached a height of some 70 metres, but even large ones seldom reach a quarter of this.

There is apparently more than one way in which a tsunami can be generated, but the most common cause is probably the sudden uplift or subsidence of an area of the ocean floor. Others are related to submarine Iandslides or slumps, and this may possibly account for the delays of as much as 4 hours between the earthquake and the generation of the tsunami that have occasionally been reported. Tsunamis have sometimes been caused by earthquakes with an epicentre on land (Gutenberg 1939), probably as a result of related slumping, though Benioff has suggested that an interaction between large surface waves and the water at the edge of the continental shelf could be responsible (Richter, 1959, p. 116). The behaviour of tsunamis certainly suggests that the source region, unlike the focus of an earthquake, frequently has an appreciable area.

\section{Tsunamis reaching New Zealand}

Once they have been generated, tsunamis are propagated to great distances with little attenuation, so that Japan is troubled by waves originating as far away as Chile, and Japanese and Aleutian earthquakes have produced damaging effects in Hawaii. Laing (1954) has listed 13 tsunamis reaching the New Zealand coast between 1848 and 1947. It has been the 
experience of the seismological observatory that reports of freak waves following the larger felt earthquakes are fairly common, but that few of these reports can be confirmed and the majority are clearly discredited. It seems likely that some of Laing's instances depending upon press reports alone are of doubtful authenticity, and in other cases the correlation with a known earthquake is poor. However, periodic tsunamis of South American origin are experienced, the most recent being associated with the Chilean shock of May 1960. In 1868 a wave from Peru caused a drowning in the Chatham Islands, the only recorded fatality. It is of interest that on this occasion the west coast of the South Island experienced the wave, as well as the east coast. Observers' estimates of its size vary from 4 ft to $15 \mathrm{ft}$, but the amount of damage reported suggests some exaggeration. The comparatively mild effects in New Zealand of South American tsunami that have been troublesome in Japan, Hawail, the Aleutians and Kamchatka is probably a consequence of the existence of the Campbell Plateau and the Chatham Rise over which the depth of water is only 500 to 1500 metres, and which extend some $800 \mathrm{~km}$ to the east of New Zealand. A wave crossing the South Pacific basin will be appreciably slowed. when it first encounters the shallower water, and can dissipate a great part of its energy before it reaches the coast.

Tsunamis of local origin are less satisfactorily documented. The Wairarapa earthquake in 1855 and the Napier earthquake of 1931, which are known to have caused land uplift, also caused the movement of water. Whether the resultant waves were sufficiently developed to be described as tsunamis must be considered a fine point of definition. The only wellobserved instance of a locally generated wave was on $1947 \mathrm{March} 26$, when an earthquake some $50 \mathrm{~km}$ east of Gisborne caused the sea to sweep into a hotel and some beach cottages north of that city, and to damage some bridges crossing the estuaries of small creeks. The epicentre of this earthquake lies close to the axis of the Hikurangi Trench. Resonance of the water in submarine trenches with the seismic waves has been suggested as a possible cause of some tsunamis.

\section{Interaction of tsunamis with other phenomena}

Although there is some risk of tsunami damage to low-lying coastal property and structures, especially in narrow harbours or estuaries, tsunamis have not contributed greatly to New Zealand earthquake damage. In some places, however, local conditions could possibly interact with a small tsunami to produce disproportionate efrects. The best example of this kind cones from the Niigata earthquake in Japan. This city lies on low sandy ground near a river mouth. A submarine earthquake some tens of kilometres to the north of the city produced a tsunami a few feet in amplitude that would not of itself have been serious. However, the time of occurrence coincided with high tide, and a fairly full river, and compaction of the sandy soil resulted in the copious release of ground-water over a large area. Neither the river nor the ground-water was able to drain in the normal way, and serious flooding persisted for several days. Some New Zealand townships are similarly situated.

All enclosed bodies of water have natural periods of oscillation depending upon their dimensions, and may resonate with the seismic waves from a large distant earthquake, or in the case of bays and harbours, be excited by the arrival of a tsunami at their mouths. At the time of the Iisbon earthquake of 1755, seiche oscillations of this kind were observed in ponds and lakes all over Europe, and more recently, the level gauges of several English reservoirs recorded oscillations due to an earthquake in Assam. Similar records have been obtained in New Zealand on flood control gauges on the rivers flowing into the Firth of Thames. These correlate 
with large earthquakes near the Kermadecs, and could be due either directIy to the arrival of small tsunamis, or more likely to resonance in the Firth or the Hauraki Gulf.

\section{Tsunami warnings}

Warning systems operate in many parts of the Pacific. For tsunamis of distant origin, the service operated from Honolulu by the United States Coast and Geodetic Survey is adequate, but in Japan it is supplemented by a local system organised by the Japan Meteorological Agency. Cooperating observatories send data to Honolulu by priority radiogram whenever a large earthquake is recorded. An epicentre is computed, and tide gauge stations in the area are asked to watch for an abnormal wave. As soon as a wave is reported, all cooperating countries are alerted, and given estimated times of arrival of the wave.

New Zealand does not regularly provide seismic data for the service, as we have no continuous watch at seismograph stations, but readings are frequent ly supplied on request from Honolulu when they would improve the accuracy of the determination, or other stations are temporarily unservicable. Apia Observatory regularly contributes information on request. The warnings issued reach New Zealand through the meteorological communications network and are passed to the Civil Defence organisation.

The New Zealand Oceanographic Institute has prepared charts of the Pacific contoured with lines giving times of travel of a tsunami to New zealand from any given point of origin (Gilmour, 1961).

It is popularly believed that large tsunamis are preceded by a withdrawal of the water. This sometimes occurs, but it depends upon the generating mechanism and the relative positions of the point of origin and the point of observation. It is therefore of only limited value as a warning, but any abnormal withdrawal of the tide should be regarded as a danger sign. It must also be remembered that a tsunami frequently consists of several waves, the first to arrive not necessarily being the largest. The time interval between the arrival of successive waves may be as much as an hour or more, and it must not be prematurely assumed that danger has passed.

\section{Conclusions}

The risk of tsunami is present in New Zealand, both from earthquakes of distant and of local origin. Historical records do not refer to any serious disasters, but low-lying areas, particularly in bays, harbours, and estuaries are vulnerable. Flooding from rivers and the drainage of ground-water expelled from alluviated areas may be aggravated by the simultaneous occurrence of a tsunami.

\section{Bibliography and references}

RICHTER, C.F., 1958: "Elementary Seismology". Freeman and Co., San Francisco. Chapter 9.

LAING, A.C.M., 1954: Note on Tsunamis reaching New Zealand. N.Z. J. Sci. and Tech. 35B: $470-2$.

GUTENBERG, B., 1939: Tsunamis and Earthquakes. Bull. Seis. Soc. America 29: $\quad 517-26$. 
HECK, N.H., 1947: List of Seismic Sea Waves. Bull. Seis. Soc. America 37: $269-86$.

U.S. Coast and Geodetic Survey 1965: Tsunami, the Story of the Seismic Sea-Wave Warning System. U.S. Dept. of Commerce, 46 pp.

GILMOUR, A.E., 1961: Tsunami Warning, Charts. N.Z. J. Geol. Geophys. 4: $132-5$. 